The Dhaka University Journal of Linguistics: Vol. 1 No.2 August, 2008 Page: 1-10, Published on August 2009 (C) Registrar, Dhaka University ISSN-2075-3098

\section{Cak numerals}

\author{
Huziwara Keisuke
}

Research Fellow,

Graduate School of Asian and African Area Studies, Kyoto University, Japan.

\begin{abstract}
Cak is a Luish language of the Tibeto-Burman language family and it is spoken mainly in the Naikhyongchari subdistrict of Bandarban district, Chittagong Hill Tracts (henceforth, CHT), Bangladesh. In this paper, I briefly describe the Cak numeral system. Numerals in Cak are basically nouns. Cak has two series of cardinal numerals: one is the native Cak numerals and the other is borrowed from Marma. The difference between these two types of numerals is reflected in the classifiers that they take: Cak numerals take native Cak classifiers whereas the numerals borrowed from Marma take classifiers of Marma origin. The native Cak numeral for 'one' is unique in two respects. First, it changes form according to its phonological environment. Second, it appears after classifiers, while the other numerals precede classifiers. Finally, I show that all the ordinal numerals are borrowed from Pali through Marma.

Key words: Cak, Marma, numerals, numeral classifiers, Tibeto-Burman languages
\end{abstract}

\section{Introduction}

Cak is a Luish language of the Tibeto-Burman language family and it is spoken mainly in the Naikhyongchari subdistrict of Bandarban district, Chittagong Hill Tracts (henceforth, CHT), Bangladesh, where the population of Cak-speaking people is
2,000 (1991 Census (BBS 2002)). In the Rakhine State, Burma (Myanmar), Cak is commonly known as Sak and the corresponding population is estimated to be at least 2,000 (Bradley 2007: 403).

Cak/Sak is often regarded as Chakma, the most dominant Tibeto-Burman ethnic minority in CHT. Although Cak/Sak and Chakma are called Oa? (Sak) in Marma and Arakanese, linguistically speaking, Cak/Sak is Tibeto-Burman, whereas Chakma is Indo-Aryan. Historically, they might be once a same people; however, there are not any definite evidences to prove it. Now they are totally different groups.

There are few linguistic reports on Cak/Sak; Löffler (1964), Bernot (1966) and Maggard et al. (2007) comprise the extant literature. Cak has 8 monophthongs /a, e, i, i, o, u, u, ə/, one diphthong /ai (appears in a closed syllable only)/ and 24 syllable initial consonants $/ \mathrm{p}, \mathrm{ph}\left[\mathrm{p}^{\mathrm{h}}\right], \mathrm{b}, \mathrm{t}, \mathrm{th}\left[\mathrm{t}^{\mathrm{h}}\right], \mathrm{d}, \mathrm{c}[\mathrm{ts}]$, ch $\left[\mathrm{ts}^{\mathrm{h}}\right], \mathrm{j}[\mathrm{dz}], \mathrm{k}, \mathrm{kh}\left[\mathrm{k}^{\mathrm{h}}\right], \mathrm{g}, \mathrm{a}, \mathrm{a}, \mathrm{v}, \mathrm{s}, \mathrm{\int}, \mathrm{h}, \mathrm{m}, \mathrm{n}, \mathrm{\eta}$ (also occurs as a syllable final), 1, r, w, y/. It also has one syllable-final consonant $/ \mathrm{P} /$ with two distinctive tones: the high tone is marked with an acute accent while the low tone is not marked.

In Cak, general grammatical information is represented as follows. Lexemes are classified into nouns, verbs and particles. Adjectives occur as a subclass of verbs or nouns depending on their syntactic positions, and adverbs, as a subclass of nouns. The most frequent word order in a sentence is SOV, although arguments may occur before or after the predicate, depending on the context. Cak has agglutinative morphology, predominantly through the use of suffixes. Temporal/procedural settings and/or modifications are formed via combinations of auxiliary verbs and predicate markers. Clause chaining occurs with the aid of various types of 
subordinating/converb-forming markers. Cak has a highly developed classifier system and a variety of "elaborate expressions" (in the sense of Matisoff (1991)). Cak also has many loan words from Marma, ${ }^{1)}$ a regional lingua franca in Bandarban district, CHT. In this paper, I focus mainly on the Cak numeral system.

\section{Cardinal numerals}

In Cak, numerals are essentially nouns, although they have a number of unique characteristics. One of the most striking characteristics of Cak numerals is that they are usually used with classifiers. Further, the Cak numeral system is basically a decimal system, and it consists of native Cak forms and forms borrowed from Marma. The difference between these two forms is reflected in the classifiers that they take (abbreviated as CL): Cak numerals generally appear with native classifiers, while Marma numerals appear with classifiers of Marma origin.

These two types of numerals are shown in Table 1. The column labeled 'Cak' shows original Cak numerals; 'Cak-Marma', the numerals borrowied from Marma; and 'Marma', the corresponding Marma numerals. The original Cak forms are always used with a classifier. Here, the general classifier $h v u$ is employed.

\begin{tabular}{|c|c|c|c|}
\hline & Cak & Cak-Marma & Marma \\
\hline 1 & $h v u ́-w a$ & tái? & toi? \\
\hline 2 & nín-hvú & nái? & hnoi? \\
\hline 3 & sún-hvú & sún & $\theta u ́ n$ \\
\hline 4 & prí-hvú & lé & lé \\
\hline
\end{tabular}

The Dhaka University Journal of Linguistics

\begin{tabular}{|c|c|c|c|}
\hline 5 & ná-hvú & நá & நá \\
\hline 6 & kruP-hvú & khró? & khro? \\
\hline 7 & sənin-hvú & khənái? & khənэi? \\
\hline 8 & ácaiP-hvú & Sáip & Soi? \\
\hline 9 & təhvú-hvú & kó & $k u$ \\
\hline 10 & $s^{\prime}-h v u$ & che & che \\
\hline
\end{tabular}

Table 1: Cak and Marma numerals from 1 to 10

It is important to note that the numeral for 'one' has two peculiarities.

(1) a. Generally speaking, numerals appear before classifiers:

nín-hvu' 'two-CL' However, in the case of the numeral for 'one', the classifier comes first: hvú-wa 'CLone'.

b. The morpheme for 'one' appears differently according to the preceding word-final sound of the preceding classifier, as shown in (2) below.

The following are examples of how various classifiers are used with the Cak numeral for 'one':

(2) a. after - ந: $\boldsymbol{n a}$ e.g. són-na 'CL:house-one'

b. after -?: ta e.g. $t a$ P-ta 'CL:leaf-one'

c. after $-i$ : $y \boldsymbol{a}$ e.g. phi-ya 'CL:cake-one'

d. after $-u$ or $-o$ : $\boldsymbol{w a}$ e.g. hú-wa 'CL:man-one', kó-wa

'CL:shrimp-one'

e. after -i: $\boldsymbol{a}$ e.g. st́-a 'CL:vegetable-one'

f. after - $a$ : $\boldsymbol{r a}$ e.g. $t a-\boldsymbol{r} \boldsymbol{a}$ 'CL:animal-one'

Note: There is no classifier which ends with $-m$ and $-e$.

Vol. 1 No.2 August, 2008 
Cak numerals from 11 to 20 are shown in Table 2 below.

\begin{tabular}{|c|c|c|c|}
\hline & Cak & Cak-Marma & Marma \\
\hline 11 & $s^{\prime}=i \eta \eta$ & təché-tái? & təchě-toi? \\
\hline 12 & śt=ín nín-hvú & təché-nái? & təchě-hnoi? \\
\hline 13 & $s_{t}=i ́ \eta$ sún-hvú & təché-sún & 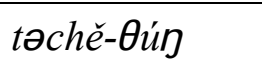 \\
\hline 14 & $s_{t}^{\prime}=i n$ pŕ́t-hvú & təché-lé & təchě-lé \\
\hline 15 & $s_{\boldsymbol{t}}^{\prime}=i ́ \eta$ ワá-hvú & təché-ワá & təchě-ワá \\
\hline 16 & $s^{\prime}=i \eta g r u P-h v u ́$ & təché-khró? & təchě-khro? \\
\hline 17 & 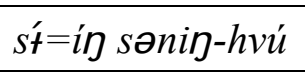 & təché-khənái? & təchě-khənכi? \\
\hline 18 & $s^{\prime}=i n$ ácaip-hvú & təché-Sái? & təchě-Soi? \\
\hline 19 & $s^{\prime}=i n$ təhvú-hvú & təché-kó & təchě-kú \\
\hline 20 & hún & náiPche & hnoi?che \\
\hline
\end{tabular}

Table 2: Cak and Marma numerals from 11to 20

There are several important points to note with respect to the numerals shown in Table 2 .

(3) a. For numerals above 11, the Marma borrowing forms are used more often.

$\mathrm{b}=i n$ in Cak forms from 11 to 19 is a comitative case marker. The Marma comitative marker $=n \breve{a}$ is also borrowed in Cak (=náP) and used with Marma numerals (Cak-Marma form): təche=náP lé '14'< təche 'ten' + =náP 'Marma comitative marker' + lé 'four'.

c. The Marma che ' 10 ' changes to -che in 11 19. Here, the rising tone functions as a genitive marker. ${ }^{3)}$ The CakMarma form reflects the original Marma rising tone through the Cak high tone -ché.

$\mathrm{d}$. The Marma che '10' does not change to -ché in numerals from 21 and above. Furhter, the Cak-Marma forms reflect this with the low tone, e.g. '21' Marma hnoi?chetoiP > Cak-Marma nái che-tái?.
Cak numerals above 30 are shown in Table 3 below.

\begin{tabular}{|c|c|c|c|}
\hline & Cak & Cak-Marma & Marma \\
\hline 30 & sún-jt & súnche & Oúnche \\
\hline 40 & práin-jt́ & léche & léche \\
\hline 50 & நáin-jt & jáche & jáche \\
\hline 60 & kruP-ćt & khróPche & khroPche \\
\hline 70 & sənin-j't & khənáiPche & khonoi?che \\
\hline 80 & ácaip-ćt & Sái?che & SoiPche \\
\hline 90 & təhvú-jí & kóche & kúche \\
\hline 100 & tərá & - & təra \\
\hline 200 & - & náiPra & hnoiPra \\
\hline 1000 & thón-na & təthó & təthon \\
\hline 2000 & - & náiPthón & hnoi?thop \\
\hline
\end{tabular}

Table 3: Cak and Marma numerals from 30 to 2000

There are several irregularities observed in the numerals shown in Table 3.

(4) a. The numeral for ' 10 ' in Cak is principally st́. However, it appears as $-c \mid t$ after the glottal stop and as $-j t$ elsewhere.

b. Excepting the numeral for ' 10 ', the numerals for round numbers do not precede classifiers. Rather, they are placed after classifiers. In these cases, nouns with classifiers are expressed as NOUN + A-CLASSIFIERNUMERAL: $a$ (PREFIX) - ha? (CL:time) - páche (fifty) 'fifty times'.

c. The numerals for ' 40 ' and ' 50 ' have exceptional morphologies. Theoretically, they should have been *pŕt-jt

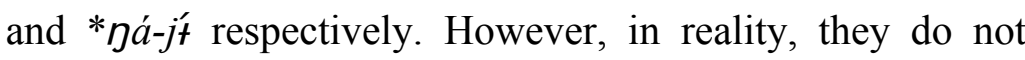


appear in this form. Originally, this might have been attributable to the comitative case marker = in: práin-jt $<$

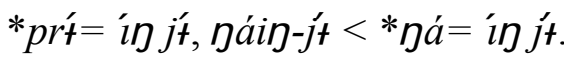

d. The numeral for ' 100 ' tərá reflects a native Cak form, while that for '200' náiPra is borrowed from Marma. This is evident from the tonal difference. Roughly speaking, the Marma high tone corresponds to the Cak low tone, and the Marma low tone corresponds to the Cak high tone (however, there are numerous exceptions to this principal rule; see Cak ' 3 ' and ' 5 ').

\section{Ordinal numerals}

All of the ordinal numerals in Cak are borrowed from Marma. The ordinal forms for 'first', 'second' and 'third' are originally from Pali. ${ }^{4)}$ They are shown in Table 4 below.

\begin{tabular}{|l|l|l|l|}
\hline & Cak-Marma & Marma & Pali \\
\hline 1st & pəthəmá & pəthəmă & pathma \\
\hline 2nd & dútiyá $\sim$ dútíyá? & dŭdəyă & dutiya \\
\hline 3rd & tátiyáP $\sim$ tátíyá? & tădəyă & tatiya \\
\hline
\end{tabular}

Table 4: Cak ordinal numerals: 1st, 2nd, 3rd

Ordinal numerals from '4th' and above are generally expressed by the combination of Cak/Marma numerals + nainbái?: '4th' pri-nainbái? < prí 'four (Cak form)' + nainbái? or lénaipbái? < lé 'four (Marma form)' + nainbái? 'number' cf. English number. ${ }^{5)}$

\section{Conclusion}

In this paper, I have briefly described the Cak numeral system. The cardinal numbers consist of native Cak native forms and forms borrowed from Marma, and they are used with their corresponding Cak or Marma classifiers. All the ordinal The Dhaka University Journal of Linguistics numbers in Cak were originally Pali. Overall, the numeral system in Cak is highly influenced by Marma, which, in turn, is greatly affected by Pali.

\section{Notes}

1. Marma is a dialect of Arakanese, a southwestern variety of Burmese. Marma has 7 vowels /a, e, i, o, o, u, ə/ and 27 syllable-initial consonants $/ \mathrm{p}, \mathrm{ph}\left[\mathrm{p}^{\mathrm{h}}\right], \mathrm{b}, \mathrm{t}, \mathrm{th}\left[\mathrm{t}^{\mathrm{h}}\right], \mathrm{d}, \mathrm{c}[\mathrm{t} 6]$, ch $\left[\mathrm{t}^{\mathrm{h}}\right], \mathrm{j}[\mathrm{d} \mathrm{z}], \mathrm{k}, \mathrm{kh}\left[\mathrm{k}^{\mathrm{h}}\right], \mathrm{g}, \mathrm{m}, \mathrm{hm}, \mathrm{n}, \mathrm{hn}, \mathrm{\eta}$ (also occurs as a syllable final), hy, l, hl, r, hr, y, w, $\theta, \int, \mathrm{h} /$. It also has one syllable-final consonant $/ \mathrm{P} /$ with four distinctive tones: the high tone, rising tone and stop tone are marked with an acute accent, hacek and word-final glottal stop, while the low tone is not marked.

2. Similar situation is observed in Kadu, a Luish language spoken in Upper Burma. Kadu call themselves [asa?] and Cak call themselves [átsa?]. Thus, they are thought to be closely related. In fact, they share many cognate sets as well as functional words such as directional auxiliary verbs. In Kadu, numerals except 'one' are borrowed from Shan, a Tai language, where classifiers always precede numerals. However, in the case of the numeral for 'one', the classifier comes first (Brown 1920: 22). It is just like the Cak case.

3. Similar tonal alternation is observed in Burmese (Okell 1969: 192).

4. The Pali forms used in this paper are based on Davids \& Stede (1921-1925).

5. There do exist Pali forms for ordinal numerals from '4th' and above. They are shown in Table 5 below. However, they are not known among the ordinary Cak-speaking people and are therefore not used. 


\begin{tabular}{|l|l|l|}
\hline & Cak & Pali \\
\hline 4th & codúPthá & catuttha \\
\hline 5th & painjəmá & pañcama \\
\hline 6th & sathəmá & chattha \\
\hline 7th & sáiPthómá & sattama \\
\hline 8th & ái?thə́má & atthma \\
\hline 9th & nowamá & navama \\
\hline 10th & dasəmá & dasama- \\
\hline
\end{tabular}

Table 5: Cak ordinal numerals of Pali origin

\section{References}

BBS (Bangladesh Bureau of Statistics) ed. 2002. Statistical

Pocketbook of Bangladesh 2000. Statistic Division, Ministry of Planning, Government of the People's Republic of Bangladesh.

Bernot, L. 1966. Eléments de vocabulaire Cak recueilli dans le Pakistan Oriental. In Ba Shin, J. Boisselier and A. B. Griswold (eds.) Papers on Asian history, religion, languages, literature, music folklore, and anthropology: essays offered to G. H. Luce by his colleagues and friends in honour of his seventy-fifth birthday, volume 1, 67-91. Ascona, Switzerland: Artibus Asiæ Publishers.

Bradley, D. 2007. East and Southeast Asia. In C. Moseley (ed.)

Encyclopedia of the world's endangered languages, 349-422. London and New York: Routledge.

Brown, R. G. 1920. The Kadus of Burma. Bulletin of the School of Oriental Studies, 1(3): 1-28.

Davids, T. W. R. and W. Stede. 1921-1925. Pali-English Dictionary. Repr. Delhi 1997: Motilal Banarsidass Publishers.

Löffler, L. G. 1964. Chakma und Sak: ethnolinguistische Beiträge zur Geschichte eines Kulturvolkes. Internationales Archiv für Ethnographie, 50(1): 72-115.
Maggard, L., M. Sangma and S. Ahmad. 2007. The Chak of Bangladesh: A Sociolinguistic Study. Dhaka: SIL Bangladesh.

Matisoff, J. A. 1991. Endangered Languages of Mainland Southeast Asia. In R. H. Robins and E. M. Uhlenbeck (eds.) Endangered Languages, 189-228. Oxford: Berg.

Okell, J. 1969. A Reference Grammar of Colloquial Burmese. London: Oxford University Press.

Email Contact: kejcxan@gmail.com 